\title{
THE STUDY OF BIOLOGICAL TISSUES AND BODILY FLUIDS OF THE HUMAN BODY USING LASER POLARIMETRIY
}

\author{
V. T. Bachinskiy, O. G. Ushenko, O. Y. Vanchulyak, Y. V. Sarkisova
}

Summary. The article presents the current status of questions concerning the diagnosis of pathological conditions for forensic practitioners. Particular attention is paid to biophysical research methods, which have evidential accuracy, objectivity, reproducibility and fast results. In our opinion, a promising direction is the study of bodily fluids, including the vitreous body, is laser polarimetry techniques that will help identify and introduce the newest optical criteria for diagnosing time of death.

Keywords: laser polarimetry, time of death, formation of hematomas, myocardial ischemia, vitreous body.

УДК 616.718-001.5-091:611.718

\section{НОВИЙ ПОГЛЯД НА БІОМЕХАНІКУ ПЕРЕЛОМІВ ДОВГИХ ТРУБЧАСТИХ КІСТОК НИЖНЬОї КІНЦІВКИ}

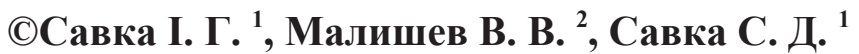 \\ ${ }^{1}$ ВДНЗ України «Буковинський державний медичний університет», \\ ${ }^{2}$ Чернівецьке обласне бюро судово-медичної експертизи, м. Чернівці
}

Резюме. Основною метою нашої роботи є розгляд сучасних аспектів біомеханіки переломів довгих трубчастих кісток нижньої кінцівки при механічній травмі. В якості об'єктів дослідження виступили 576 зразків та 128 експертних випадків 3 ушкодженнями стегнової, велико- та малогомілкової кісток. Отримані дані піддані статистичній обробці 3 використанням багатофакторного дисперсійного аналізу. У роботі встановлено, що для визначення механо- та морфогенезу переломів довгих трубчастих кісток нижньої кінцівки найбільш доцільно використовувати три згруповані ієрархічні біомеханічні модулі: пружності, жорсткості та міцності, які включають найвагоміші діагностичні значимі морфологічні ознаки, згруповані за ступенем їх впливу на процеси руйнації вказаних кісток.

Ключові слова: нижня кінцівка, довгі трубчасті кістки, переломи, морфологічні ознаки, біомеханіка травми.

ВСТУП. На сучасному етапі розвитку судово-медичної науки біомеханіка переломів включає вирішення комплексу спеціальних завдань. По перше - це встановлення параметрів засобу, що спричинив перелом. Зазвичай, фахівці вирішують це питання за морфологічними особливостями різних зон руйнації кістки та видами деформацій, які спричинив травмуючий предмет. По друге - це врахування анатомо-функціональних особливостей кісткової тканини, що сприймає навантаження. Загальновідомо, що структурно-функціональні особливості травмованої кістки чинять суттєвий вплив, а в ряді випадків є визначальними у виникненні морфологічної картини переломів різних кісток скелета людини. Насамкінець, лікарі судово-медичні експерти та криміналісти мають максимально точно і повно відновити умови за яких відбулася взаємодія травмуючого предмета і травмованої ділянки.

Фактори, що формують вказані комплекси достатньо повно описані та проілюстровані в діагностикумі механізмів і морфології переломів при тупій травмі скелета - монографії, виданій під керівництвом професора Крюкова В.Н. [1].

У той же час, сучасні методи дослідження кісткової тканини, комп'ютерної візуалізації ділянки перелому, статистичної обробки значного об’єму цифрового матеріалу, що всебічно характеризують морфологічні ознаки різних зон ділянки перелому довгих трубчастих кісток та їх структурні особливості - дозволяють поглибити знання, які розкривають біомеханіку переломів вказаних кісток і вивести нові закономірності у перебігу процесу їх руйнації.

Також все більше закордонних науковців у своїх дослідженнях вказують на необхідності біомеханічних досліджень процесу руйнації довгих кісток нижньої кінцівки та впливу окремих морфологічних компонентів кісткової тканини на перебіг процесу їх руйнації: G.E. Sroga, V. Kosmopoulos, S. Nagaraja, E.I. Waldorff та iн. [2, 3, 4, 5].

Мета дослідження. Розглянути сучасні аспекти біомеханіки переломів довгих трубчастих кісток нижньої кінцівки при механічній травмі, для об’єктивного ретроспективного встановлення механізмів їх виникнення.

Матеріал і методи дослідження. В якості матеріалу дослідження взяті 576 зразків стегнової, велико- і малогомілкової кісток, що вилучені із 16-ти біоманекенів чоловічої та жіночої статей віком від 24 до 70 років без ïx травматичних ушкоджень, видимих патологічних змін чи згадок про такі в анамнезі. Експертні дослідження включали 82 особи зі 128 ушкодженнями нижніх кінцівок: стегна - 40 випадків, великогомілкової кістки - 46 випадків, малогомілкової - 42 випадки. Отримані дані піддавали статистичній обробці з використанням багатофакторного дисперсійного аналізу. 


\section{РЕЗУЛЬТАТИ ДОСЛІДЖЕННЯ ТА ЇХ ОБГОВОРЕННЯ.}

Травматичні ушкодження досліджуваних кісток у всіх випадках мали значний масштаб. Текстура порушень (морфологічна картина площини перелому) цілісності кістки відображалася у різноманітних характеристиках і коефіцієнтах у зонах розриву та долому. Травматичні деформації нижніх кінцівок різнилися між різними довгими трубчастими кістками, оскільки з них складалися дві кінематичні зони: стегна (з однієї кісткою) та гомілки (де дві кістки формували механічну двохопорну балку). Окрім того, на характеристики переломів впливав стан м'язово-фасціального каркаса та фіксуючого механізму суглобів.

При дії тупих предметів відбувалося поглинання енергії кістковою тканиною з виникненням ушкоджень. У зоні розриву механічна дія була меншою, ніж у зоні долому (коефіцієнт ушкодження відносно товщини компактної кістки $0,48 \pm 0,01$ проти $0,54 \pm 0,01$ відповідно, з р $<0,05$ ), що вказує на більшу опірність ДТК нижньої кінцівки до розтягнення, ніж до стиснення. Визначення коефіцієнтів протяжності зони розриву відносно діаметра кістки та відносно товщини компактної речовини в різних відділах кісток вказує на незначну різницю між цими зонами (рис. 1). Особливою є ділянка кістки в нижній (дистальній) частині стегна, де величина розриву відносно товщини компакти кістки є більшою, ніж така ж величина в зоні долому.

Схожі зміни спостерігалися і в зонах пластичної деформації кісткової тканини. Максимальна протяжність зони деформації з боку розриву досягала $0,32 \mathrm{~cm}$, у той час як у зоні долому вона була дещо вищою $-0,50 \mathrm{cм}$. Загальні закономірності цього показника вказують на пряму залежність від окружності кістки: на стегновій вони більші, ніж на великогомілковій кістці, найменші на малогомілковій, коефіцієнт кореляції з окружністю кістки 0,76 та 0,75 відповідно $(\mathrm{p}<0,05)$. Але в межах окремих кісток спостерігаються нелінійні зміни, які скоріше за все пов'язані зі структурою кістки, - пряма кореляція з вмістом органічних речовин $(\mathrm{r}=0,25, \mathrm{p}<0,05)$ й зворотна 3 мінеральною складовою в даній ділянці ( $\mathrm{r}=-0,25$ та $\mathrm{r}=-0,26$ відповідно, $\mathrm{p}<0,05)$.

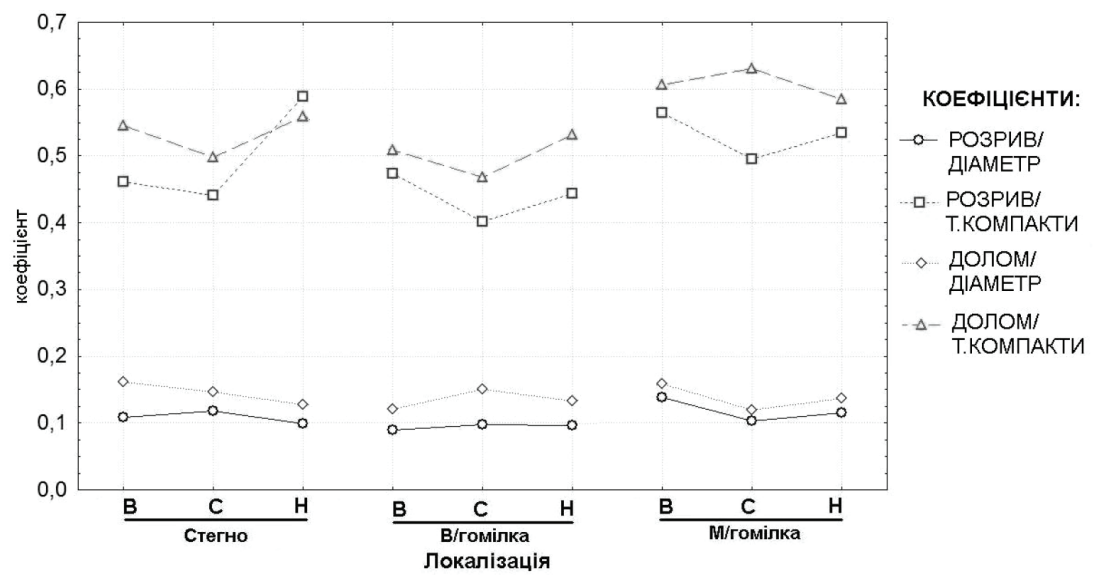

Рис. 1. Структурні особливості переломів за даними коефіціснтів розриву та долому в різних відділах довгих трубчастих кісток нижньої кінцівки.

У подальшому нами були детально досліджені закономірності формування зубців, різних видів тріщин в окремих відділах довгих кісток нижньої кінцівки.

Зона травми супроводжується деформацією із розшаруваннями, згинами, мікротріщинами та руйнацією кісткової тканини. У напрямку дії вектора сили утворюються сколи та гребені з зубчастою поверхнею. У зоні розлому руйнація кістки супроводжується утворенням нерівної поверхні з зубцями (у 19 \% випадків) і кількістю зубців від 1 до 3. Найбільша кількість зубців реєструється в нижній (дистальній) третині стегна.

У зоні долому, зазвичай, утворюється високий гребінь із висотою від 0,65 см до 8,29 см $(2,35 \pm 0,12$ у середньому значенні). Цікавою $є$ його характеристика на великогомілковій кістці, де найвищий рівень має гребінь середньої частини кістки.

Отримана травма супроводжувалась утворенням значної кількості тріщин кістки різного типу. У цілому частота утворення тріщин та їх кількість залежать від обставин і важкості травми. У той же, час різні типи тріщин мають свої максимальні показники за кількістю, що відображає механіку перелому. При утворенні тріщин, окрім механічної дії на кістку фізичної сили, значну роль відіграють фізико-хімічні властивості самої кістки, iї склад та геометрична будова.

Серед більшості діагностичних морфологічних ознак кут відходження клиноподібних тріщин найбільш інформативно вказував на характер дії фізичної сили. Так, при травмі, викликаній ударом зі згином, величина кута в середньому становила $(34,9 \pm 1,0)^{\circ}(95 \% \mathrm{CI}=22,9-36,9)$, дія сили зі скручуванням супроводжувалася виникненням клиноподібних тріщин під середнім кутом $(31,7 \pm 4,1)^{\circ}(95 \%$ CI=23,7-39,7), а при дії на кістку стискаючої 
сили вказаний кут був вірогідно найменшим - $(24,1 \pm 1,3)^{\circ}(95 \% \mathrm{CI}=21,6-26,6),(\mathrm{p}<0,05)$. Отже, цей показник має важливе діагностичне значення при визначенні характеру дії фізичної сили.

Для встановлення зв'язків між травмуючими факторами, значною кількістю показників морфологічних особливостей будови кістки та характеристик переломів був використаний багатофакторний дисперсійний аналіз. При цьому відібрано 20 найбільш суттєвих показників для групування їх у меншу кількість факторів (табл. 1).

Таблиия 1

Багатофакторний дисперсійний аналіз зв'язків між видом дії та морфологічними ознаками зони перелому кісток

\begin{tabular}{|c|c|c|c|c|}
\hline \multirow{2}{*}{$\begin{array}{l}\text { № } \\
\text { 3/ח }\end{array}$} & \multirow{2}{*}{ Ознака, показник } & \multicolumn{3}{|c|}{ Номер фактора } \\
\hline & & фактор 1 & фактор 2 & фактор 3 \\
\hline 1. & Характер дії травмуючої сили & 0,135 & 0,086 & 0,571 \\
\hline 2. & Площа кістково-мозкової порожнини & 0,348 & 0,329 & 0,536 \\
\hline 3. & $\begin{array}{l}\text { Протяжність зони пластичної деформації з боку розтяг- } \\
\text { нення }\end{array}$ & 0,014 & 0,324 & 0,780 \\
\hline 4. & Кількість зубців у зоні розриву & 0,233 & $\mathbf{0 , 4 0 7}$ & 0,010 \\
\hline 5. & Кількість деревоподібних тріщин з боку розтягнення & 0,207 & 0,270 & $-0,035$ \\
\hline 6. & Кількість поздовжніх тріщин з боку розтягнення & $-0,100$ & $-0,019$ & 0,158 \\
\hline 7. & $\begin{array}{l}\text { Кількість тріщин від кістково-мозкової порожнини } 3 \\
\text { боку розтягнення }\end{array}$ & 0,267 & 0,328 & 0,068 \\
\hline 8. & Протяжність зони пластичної деформації з боку стиснення & $-0,073$ & 0,397 & 0,694 \\
\hline 9. & Висота найбільшого гребеня в зоні долому & $-0,034$ & 0,411 & $\mathbf{0 , 3 0 1}$ \\
\hline 10. & Кількість клиноподібних тріщин від зони долому & $-0,076$ & 0,662 & 0,098 \\
\hline 11. & Довжина найбільшої клиноподібної тріщини & 0,125 & 0,588 & 0,513 \\
\hline 12. & Кут відходження клиноподібних тріщин & 0,040 & $-0,165$ & 0,642 \\
\hline 13. & $\begin{array}{l}\text { Кількість тріщин від кістково-мозкової порожнини } 3 \\
\text { боку стиснення }\end{array}$ & 0,102 & 0,602 & 0,468 \\
\hline 14. & Кількість Х-У тріщин з боку стиснення & 0,066 & 0,651 & 0,278 \\
\hline 15. & Кількість поздовжніх тріщин з боку стиснення & 0,065 & 0,622 & 0,485 \\
\hline 16. & Загальна кількість пор, \% & 0,925 & 0,072 & $-0,061$ \\
\hline 17. & Загальна органічна складова кістки, \% & 0,859 & $-0,375$ & 0,034 \\
\hline 18. & Загальна мінеральна складова кістки, \% & $\mathbf{0 , 5 0 0}$ & $-0,429$ & 0,323 \\
\hline 19. & Щільність мінеральна & 0,670 & $-0,589$ & 0,239 \\
\hline 20. & Щільність загальна & 0,643 & $-0,575$ & 0,165 \\
\hline
\end{tabular}

Із наведеної таблиці видно, що фактор 1 (загальна значимість якого складає 4,92) переважно включає морфологічні показники. Подальший аналіз його вказує на те, що він фактично описує модуль пружності кістки. Так, найбільш вагомими ознаками у його складі $є$ загальна кількість пор та загальна частка органічних речовин у складі кістки. Мінеральна складова має дещо меншу вагу і вона включає мінеральну густину та відсоток мінеральної складової кістки. Важливим фактором є площа медулярного каналу, з яким пов'язана кількість тріщин від медулярного каналу з боку розтягнення.

Вага фактора 2 у цьому відношенні значно менша (величина 3,59). Він описує біомеханічні закономірності ушкоджень, пов'язані з модулем жорсткості кістки. У цьому факторі ієрархічно виділяються найбільш важливі показники перелому: кількість тріщин (клиноподібних від долому, Х-У тріщин, поздовжніх та від медулярного каналу з боку стиснення), довжина найбільшої клиноподібної тріщини, висота найбільшого гребеня в зоні долому, кількість зубців у зоні розриву, протяжність зони пластичної деформації з боку стискання, а також емпірична морфологічна ознака - площа медулярного каналу.

Фактор 3 (величина 6,27) ієрархічно є найбільш вагомим. Він достатньо повно описує взаємодію травмуючої механічної сили із структурами кістки та її ушкодженнями, пов’язаними із модулем міцності кістки. Найважливішою ознакою у його складі є протяжність зон пластичної деформації з боку розтягнення та стиснення. У попередньому аналізі звернув на себе увагу кут відходження клиноподібних тріщин, який і в складі фактора 3 займає провідне місце поряд із характером дії травмуючої сили. Значу вагу мають також площа медулярного каналу, довжина найбільшої клиноподібної тріщини, кількість поздовжніх тріщин та від медулярного каналу 3 боку стискання, загальна мінеральна складова кістки та висота найбільшого гребеня в зоні долому. 


\title{
ВИСНОВКИ
}

1. Різні ділянки довгих трубчатих кісток нижньої кінцівки мають значну кількість структурнофункціональних особливостей. Це знаходить своє відображення у макро- та мікроархітектурі кістки і впливає на опірність до дії зовнішніх механічних сил та морфологічні характеристики переломів цих кісток.

2. Для визначення механо- та морфогенезу переломів довгих трубчастих кісток нижньої кінцівки найбільш доцільно використовувати три згруповані ієрархічні біомеханічні модулі: пружності, жорсткості та міцності, які включають найвагоміші діагностичні значимі морфологічні ознаки, згруповані за ступенем їх впливу на процеси руйнації вказаних кісток.

Перспективи подальших досліджень. Перспектива подальших досліджень полягає у подальшому поглибленому вивченні взаємозв’язків між основними структурними компонентами кісткової тканини та закономірностями формування морфологічних ознак при переломах інших кісток скелета людини.

\section{Література}

1. Диагностикум механизмов и морфологии переломов при тупой травме скелета / отв. ред. : В. Н. Крюков. Изд. 2-е, перераб. - Новосибирск : Наука, 2011. - 515, [6] с.

2. Biochemical characterization of major bone-matrix proteins using nanoscale-size bone samples and proteomics methodology / [G. E. Sroga, L. Karim, W. Colón, D. Vashishth] // Mol. Cell. Proteomics. - 2011. - Vol. 10, № 9. P. 110 .

3. Kosmopoulos V. Predicting trabecular bone microdamage initiation and accumulation using a non-linear perfect damage model / V. Kosmopoulos, T.S. Keller // Med. Eng. Phys. - 2008. - № 30. - P. 725-732.

4. Nagaraja S. Trabecular bone microdamage and microstructural stresses under uniaxial compression / S. Nagaraja, T. L. Couse, R. E. Guldberg // J. Biomech. - 2005. - № 38. - P. 707-716.

5. Waldorff E.I. Age-dependent microdamage removal following mechanically induced microdamage in trabecular bone in vivo / E.I. Waldorff, S.A. Goldstein, B.R. McCreadie // Bone. - 2007. - Vol. 40. - № 2. - P. $425-432$.

\section{НОВЫЙ ВЗГЛЯД НА БИОМЕХАНИКУ ПЕРЕЛОМОВ ДЛИННЫХ ТРУБЧАТЫХ КОСТЕЙ НИЖНЕЙ КОНЕЧНОСТИ}

\author{
Савка І. Г., Малишев В. В., Савка С. Д.
}

\begin{abstract}
Резюме. Основной целью нашей работы является рассматривание современных аспектов биомеханики переломов длинных трубчатых костей нижней конечности при механической травме. В качестве объектов исследования использовали 576 образцов и 128 экспертных случаев повреждений бедренной, большой и малой берцовой кости. Полученные данные статистически обработаны последствием многофакторного дисперсионного анализа. В работе показано, что для установления механо- и морфогенеза переломов длинных трубчатых костей нижней конечности наиболее целесообразно применять три сгруппированных иерархических биомеханических модуля: упругости, жесткости и прочности, которые включают самые весомые диагностические значимые морфологические признаки, объединенные по степени их влияния на процессы разрушения указанных костей.
\end{abstract}

Ключевые слова: нижняя конечность, длинные трубчатые кости, переломы, морфологические признаки, биомеханика травмы.

\section{A NEW SIGHT ON THE BIOMECHANICS OF FRACTURES OF THE LOWER EXTREMITY LONG TUBULAR BONES}

\author{
Savka I. G., Malyshev V. V., Savka S. D.
}

Summary. The main objective of our work is to study of the modern aspects of the biomechanics of fractures of the lower extremity long tubular bones in cases of mechanical trauma. The objects of our studies were 576 samples and 128 expert cases with injuries of the femoral bones, tibia and fibula. The data obtained were statistically processed with the use of multi-factor dispersion analysis. Three grouped hierarchical biomechanical modules have been found to be the most reasonable to apply in detection of mechanical and morphogenesis of fractures of low extremity long tubular bones: elasticity, stiffness and solidity including the most valuable diagnostic morphological signs grouped by the degree of their influence on destructive processes of the given bones.

Objective: to study of the modern aspects of the biomechanics of fractures of the lower extremity long tubular bones in cases of mechanical trauma for objective retrospective establishment of the mechanisms of fracture formation.

Materials and methods. The material of our study included 576 samples of the femoral bone, tibia and fibula, taken from 16 male and female biomannequins aged from 24 to 70 without their traumatic injuries, visual pathological changes or some mentions about them in the anamnesis. Expert examinations involved also 82 individuals with 128 injures of the lower extremities: femurs - 40 cases, tibia -46 cases, fibula -42 cases. The data obtained were statistically processed with the use of multi-factor dispersion analysis. 


\title{
Conclusions:
}

1.Various portions of long tubular bones of the lower extremity have a number of structural-functional peculiarities. It is presented in macro- and micro-architecture of the bone and influences upon the resistance to external mechanical forces and morphological characteristics of fractures of these bones.

2. Three grouped hierarchical biomechanical modules have been found to be the most reasonable to apply in detection of mechanical and morphogenesis of fractures of low extremity long tubular bones: elasticity, stiffness and solidity including the most valuable diagnostic morphological signs grouped by the degree of their influence on destructive processes of the given bones.

Prospects of further studies. The prospects of future studies consists of further comprehensive examination of interrelations between the main structural components of the osseous tissue and regularities of formation of morphological signs in case of fractures of various bones of the human skeleton.

Key words: lower extremity, long tubular bones, fractures, morphological signs, biomechanics of trauma.

\section{МЕТОД ПРОСТОРОВО-ЧАСТОТНОЇ ФІЛЬТРАЦІЇ ПОЛЯРИЗАЦЙНИХ МАП ЗОБРАЖЕНЬ ПОЛІКРИСТАЛІЧНИХ ПЛІВОК ЛІКВОРУ ДЛЯ ВИЗНАЧЕННЯ ДАВНОСТІ НАСТАННЯ СМЕРТІ}

\author{
СГараздюк М. С. \\ ВДНЗ «Буковинський державний медичний університет» \\ Кафедра судової медицини та медичного правознавства
}

\begin{abstract}
Анотація. В останні роки розробляється багато нових методик по визначенню давності настання смерті (ДНС) і одними із перспективних є лазерні поляриметричні методи, які дозволяють із високою точністю та об'єктивністю дослідити біологічні тканини для різних інтервалів посмертного періоду.

Експериментальна частина містить результати дослідження часової динаміки посмертних змін біохімічної структури полікристалічних плівок ліквору шляхом визначення величини статистичних моментів 3-го і 4-го порядків, які характеризують координатні розподіли значень азимута поляризації просторово-частотно відфільтрованих зображень полікристалічної мережі біохімічних кристалів.

Шляхом узагальнення часових залежностей статистичних моментів 3-го і 4-го порядків поляризаційних мап великомасштабної та дрібномасштабної складових полікристалічних мереж плівок ліквору у межах статистично достовірних груп зразків визначено інтервали та точність установлення ДНС.
\end{abstract}

Ключові слова: давність настання смерті, ліквор, лазерна поляриметрія.

ВСТУП. Питання визначення часу, що минув після настання смерті, було і залишається одним із найбільш актуальних та водночас і найбільш проблемних у судово-медичній практиці [4]. В останні роки розробляється багато нових методик по визначенню давності настання смерті (ДНС) і одними із перспективних є лазерні поляриметричні методи $[1,3,9]$, які дозволяють із високою точністю та об'єктивністю дослідити біологічні тканини (БТ) для різних інтервалів посмертного періоду та встановити сукупність диференційних критеріїв для об'єктивної діагностики різних патологічних станів та визначення ДНС за комплексом поляризаційних, матричних, статистичних та кореляційних параметрів лазерних зображень БТ різної морфологічної будови.

На даний час мало вивченими є можливості об’єктивного визначення ДНС шляхом дослідження посмертних змін структури поляризаційно-неоднорідних зображень біологічних рідин людини.

Мета роботи: якомога точніше та об’єктивніше установити інтервал ДНС шляхом статистичного аналізу динаміки посмертних змін координатних розподілів значень азимута поляризації (КРЗАП) зображень полікристалічних плівок ліквору (ППЛ), використавши метод двомірного стокс-поляриметричного просторовочастотного картографування різномасштабних складових біологічних шарів.

Матеріали і методи дослідження. Об'єктом дослідження є ППЛ, які забрані в 67 трупів (основна група дослідження) віком від 23-х до 91-го року з попередньо відомим часом настання смерті, що становив від 1 до 42 год, та 20 здорових добровольців (група порівняння). Відбір ліквору здійснювався методом субокципітальної пункції з великої потиличної цистерни у трупів та при спінальній анестезії при підготовці до оперативних втручань у здорових добровольців. До основної групи відбирали ліквор від трупів, що померли від серцево-судинної патології - 52 випадки (77,62\%), від туберкульозу легень - 7 випадків (10,44\%), від пухлин різних відділів шлунково-кишкового тракту - 8 випадків (11,94\%). За часом,що минув після смерті, розподіл наступний: 1-7 год - 19 випадків (28,36\%), 8-13 год - 16 випадків $(23,88 \%), 14-20$ год - 12 випадків $(17,92 \%), 20-26$ год - 10 випадків $(14,92 \%), 20-26$ год - 10 випадків (14,92\%). 